\title{
Green fluorescent protein as a reporter of prion protein folding Snezana Vasiljevic ${ }^{\dagger}$, Junyuan Ren ${ }^{\dagger}$, YongXiu Yao, Kevin Dalton, Catherine S Adamson and Ian M Jones*
}

Address: School of Animal and Microbial Sciences, The University of Reading, Reading RG6 6AJ, UK

Email: Snezana Vasiljevic - s.vasiljevic@rdg.ac.uk; Junyuan Ren - j.y.ren@rdg.ac.uk; YongXiu Yao - yongxiu.yao@bbsrc.ac.uk; Kevin Dalton - kevindaltoncpfc@yahoo.com; Catherine S Adamson - cadamson@ncifcrf.gov; Ian M Jones* - i.m.jones@rdg.ac.uk

* Corresponding author †Equal contributors

Published: 29 August 2006

Virology Journal 2006, 3:59 doi:10.1 186/1743-422X-3-59

This article is available from: http://www.virologyj.com/content/3/I/59

(C) 2006 Vasiljevic et al; licensee BioMed Central Ltd.

This is an Open Access article distributed under the terms of the Creative Commons Attribution License (http://creativecommons.org/licenses/by/2.0), which permits unrestricted use, distribution, and reproduction in any medium, provided the original work is properly cited.

\begin{abstract}
Background: The amino terminal half of the cellular prion protein $\mathrm{PrPc}$ is implicated in both the binding of copper ions and the conformational changes that lead to disease but has no defined structure. However, as some structure is likely to exist we have investigated the use of an established protein refolding technology, fusion to green fluorescence protein (GFP), as a method to examine the refolding of the amino terminal domain of mouse prion protein.
\end{abstract}

Results: Fusion proteins of PrPc and GFP were expressed at high level in E.coli and could be purified to near homogeneity as insoluble inclusion bodies. Following denaturation, proteins were diluted into a refolding buffer whereupon GFP fluorescence recovered with time. Using several truncations of $\mathrm{PrPc}$ the rate of refolding was shown to depend on the prion sequence expressed. In a variation of the format, direct observation in E.coli, mutations introduced randomly in the PrPc protein sequence that affected folding could be selected directly by recovery of GFP fluorescence.

Conclusion: Use of GFP as a measure of refolding of PrPc fusion proteins in vitro and in vivo proved informative. Refolding in vitro suggested a local structure within the amino terminal domain while direct selection via fluorescence showed that as little as one amino acid change could significantly alter folding. These assay formats, not previously used to study PrP folding, may be generally useful for investigating PrPc structure and PrPc-ligand interaction.

\section{Background}

The cellular prion protein $\mathrm{PrPc}^{\mathrm{c}}$ is a glycosylinositol phospholipid (GPI) anchored glycoprotein present on neuronal and other cells $[1,2]$ with a demonstrable ability to bind and transport copper ions [3-6]. The protein is essential for susceptibility to the Transmissible Spongiform Encephalopathies (TSEs) where the accumulation of a disease associated conformational variant, $\mathrm{PrPSc}$, is dependent on the presence of the cellular $\mathrm{PrPc}^{\mathrm{c}}$ isoform (for reviews [7-9]). A role for prion protein in copper metabolism may be linked to cell resistance to oxidative stress and, thereby, to pathology [10-16]. The C-terminal domain of mouse PrPc, whose structure has been determined by NMR, has three $\alpha$-helices and a short section of antiparallel $\beta$-sheet [17]. It folds quickly in vitro to a stable structure largely unaffected by amino acid substitution $[18,19]$. By contrast, the N-terminal domain of $\mathrm{PrPc}^{\mathrm{c}}$ is flexibly disordered in the full-length molecule $[20,21]$. This region encodes the octarepeat motifs (residues 23-90) responsible for low affinity copper binding [3,4,22-24] and the central hydrophobic region of $\operatorname{PrPc}^{\mathrm{c}}$ observed to be toxic to cells in culture [25], that also binds copper 
$[6,15,26]$ and is involved in the conversion of $\operatorname{PrPc}$ to $\operatorname{PrPsc}$ [27-29]. Prion diseases have been proposed to be essentially diseases of protein folding [30-32] in which misfolded $\mathrm{PrP}^{\mathrm{c}}$, triggered by the presence of PrPsc, forms aggregates associated with toxicity. Equally, misfolded $\mathrm{PrPc}^{\mathrm{c}}$ could be linked to disease through failure to fulfil its normal function, possibly in copper transport $[6,33,34]$. In keeping with these models, antibodies or tagged $\mathrm{PrP}^{\mathrm{c}}$ that compete for prion protein interaction prevent the accumulation of PrPsc $[35,36]$ and subsequent pathology $[37,38]$. Pathology could also result from aberrant or amplified signalling, leading to apoptosis, a situation mimicked by the binding of antibodies that cross link cell surface $\operatorname{PrPc}^{\mathrm{C}}$ [39]. Interestingly, antibodies that cause apoptosis map to the unstructured domain (residues 95105) while those binding to the structured C-terminal half of $\mathrm{PrP}^{\mathrm{c}}$ are not active [39]. Thus, methods that address prion protein folding may help describe the exact link between folding and the various properties ascribed to the $\mathrm{PrPc}^{\mathrm{c}}$ molecule. We have investigated a methodology developed originally to improve the expression of proteins for structural studies [40-42] to report on prion protein folding. Using constructs with endpoints reported previously to alter expression levels [43] we show that PrPc-GFP fusions protein can be refolded in vitro and that folding is related to the sequence of the $\mathrm{PrPc}^{\mathrm{c}}$ expressed. In addition, mutations that directly affect folding can be selected from a random expression libraries based of the recovery of GFP fluorescence. The use of a co-folding partner thus offers an indirect measure of prion protein folding both in vivo and in vitro.

\section{Results}

\section{Establishment of PrPc_GFP refolding in vitro}

The chromophore of GFP is made up of the tripeptide sequence Ser-Tyr-Gly that cyclizes in the folded form of the protein $[44,45]$. Denaturation and reduction abolish fluorescence but it can be recovered by dilution into a refolding buffer where the rate of fluorescence re-acquisition parallels protein folding $[46,47]$. GFP extended at the $\mathrm{N}$-terminus can also be refolded with a similar recovery of fluorescence $[40,41]$. To assess this technology as a measure of $\mathrm{PrP}^{\mathrm{c}}$ folding, we expressed GFP appended at the $\mathrm{N}$ terminus with the complete mature prion protein (residues 23-231) and a short fragment of $\mathrm{PrPc}^{\mathrm{c}}$, residues 76156 , as a control for the effect of size of the amino terminal extension on refolding (Fig 1A). Expression of the PrPc

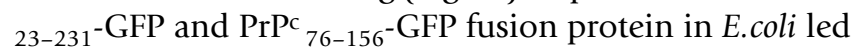
to the accumulation of non-fluorescent insoluble inclusion bodies that were purified to 90\% (Fig 1B) and then denatured before dilution into refolding buffer. GFP fluorescence $(510 \mathrm{~nm})$ rose with time to a maximum refolding level of $\sim 6$ fold for $\operatorname{PrPc}_{23-231}$-GFP and $\sim 25$ fold for $\mathrm{PrP}^{\mathrm{C}}{ }_{76-156^{-}}$-GFP over background within $3 \mathrm{hrs}$ under the conditions of the experiment (Fig 1C). Ranging experi-
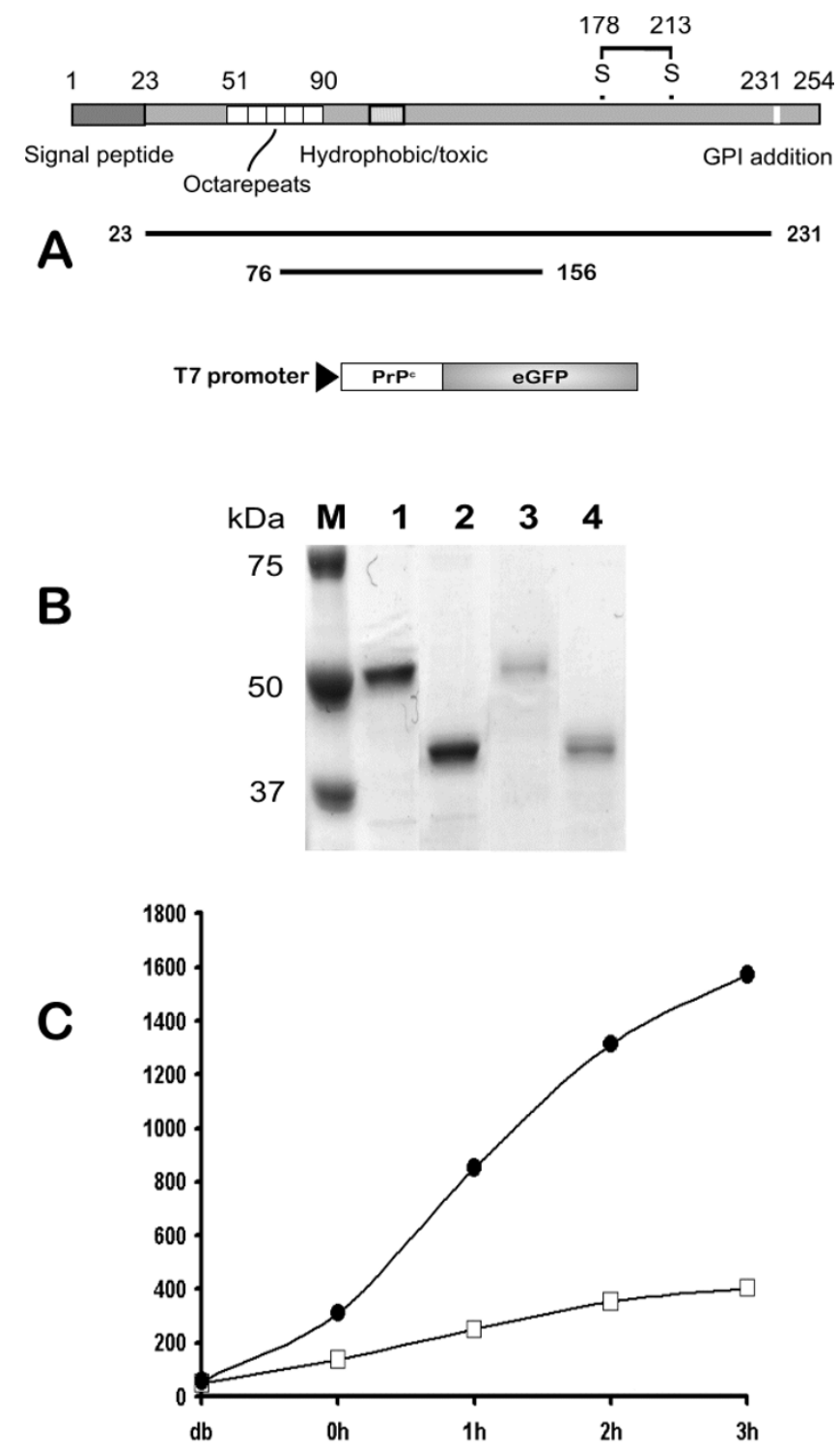

Figure I

Establishment of the Prp-GFP refolding assay. A. Fragments of the mouse prnp a allele whose structure is shown were amplified by PCR and positioned at the $\mathrm{N}$ terminus of GFP in a E.coli expression vector under transcriptional control of the T7 promoter. B. Purified PrP-GFP fusion proteins were analysed by 10\% SDS-PAGE before (lanes I \& 2) and after (lanes $3 \& 4)$ the refolding reaction. The lanes are: M-Molecular weight markers as shown; I\&3-PrP $23-231^{-G F P ; ~ 2 \& 4-P r P ~} 76-156^{-}$ GFP. The lower staining intensity of the refolded samples is due to dilution in the refolding buffer. C. Recovery of fluorescence with time following dilution of the solublised PrPGFP fusion proteins into refolding buffer. In this experiment the increase in fluorescence units was 6 fold $(\square)$ and 27 fold (O) for $\mathrm{PrP}_{23-231}$-GFP and $\mathrm{PrP}_{76-156}$-GFP respectively. Assays were done in duplicate and the average fluorescent units plotted against time. 
ments showed optimal refolding to occur at $>\mathrm{pH} 8$ and at $21^{\circ} \mathrm{C}$ (not shown). We conclude from this data that 1 ) $\mathrm{PrP}^{\mathrm{c}}$-GFP fusion proteins can refold in vitro to regenerate the GFP chromophore and 2) the level of refolding is related to the $\mathrm{PrPc}^{\mathrm{c}}$ sequence fused to GFP as alteration of the fragment size altered the rate of fluorescence recovery. The observed fluorescence was directly attributable to refolding of $\mathrm{PrP}^{\mathrm{c}}$-GFP as re-examination of the fusion proteins after the refolding assay showed full length protein in solution with no evidence of breakdown to release free GFP (Fig. 1B). As PrPc binds both copper $[3,4,26,48,49]$ and RNA [50-52] the effect of both of these ligands on the refolding reaction of full length prion protein present in

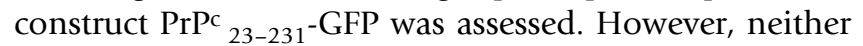
addition of copper (100 nM) nor RNA, prepared as described [51], significantly altered the rate of fluorescence recovery for the full length prion protein, which remained slow when compared to the shorter variant (see Additional file 1).

\section{Use of GFP refolding to assess the role of the extreme $\mathbf{N}$ terminus}

Previous expression of $\mathrm{PrPc}_{-} \mathrm{GFP}$ fusion proteins within eukaryotic cells indicated a marked effect of the extreme $\mathrm{N}$-terminal basic residues $23-28$ on prion protein processing $[53,54]$ and further studies have suggested an interaction between the extreme amino terminus and the $\mathrm{C}$ terminal folded domain [43] extending an earlier antibody binding study [55]. In order to assess directly if the $\mathrm{N}$ terminal sequence affects folding per se, amino terminal truncations were made in which $\mathrm{PrPc}^{\mathrm{c}}$ residues 23-156, 29-156, 23-169 and 29-169 (see 1) were appended to the $\mathrm{N}$ terminus of GFP and the fusion proteins purified as an insoluble fraction prior to dilution into the refolding reaction (Fig. 2A). When equimolar amounts of each fusion protein were subjected to the refolding assay, the rates of fluorescence reacquisition were found to vary considerably (Fig. 2B). The presence of residues $23-28$ at the extreme N-terminus of $\mathrm{PrP}^{\mathrm{c}}$ severely limited refolding in the context of a fragment truncated at residue 156 with overall refolding little better than the complete 23-231 $\mathrm{PrPc}^{\mathrm{c}}$ sequence despite being a considerably shorter fragment ( $c f$ Fig. 1). Deletion of residues 23-28 (construct $\mathrm{PrPc}_{29-156}$-GFP) enhanced fluorescence recovery $\sim 4$ fold when compared to $\operatorname{PrPC}_{23-156}$-GFP (Fig. 2B). However, a fragment starting at residue 23 but with an extended C-terminal truncation point at residue 169 ( $\left.\mathrm{PrPc}_{23-169}-\mathrm{GFP}\right)$, refolded far more efficiently than $\operatorname{PrPc}_{23-156}$-GFP (Fig. 2B) and deletion of the amino terminal 6 residues in $\mathrm{PrPc}_{29-}$ ${ }_{169}$-GFP failed to improve the level of fluorescence observed. Fluorescence recovery was associated with equivalent quantities of soluble full-length fusion protein as no free GFP was apparent when the refolded samples were analysed by SDS-PAGE after removal from the refolding reaction (Fig. 2A). Thus, recovery of fluores- cence by PrPc-GFP fusion proteins in vitro following denaturation and renaturation measures a direct role for residues $23-28$ and $156-169$ in folding and mirrors the expression patterns observed for prion protein fragments of the same endpoints in vivo [43].

\section{Use of GFP for direct selection of folding variants}

That GFP fluorescence recovered in vitro reflected properties measured in eukaryotic cells suggested that PrPc-GFP fusions retained a degree of physiological significance. We sought therefore to use fluorescence for the direct selection of prion mutants with altered folding properties. To do this we used the plasmid encoding $\operatorname{PrPC}_{23-231}$-GFP as template for error prone PCR based mutagenesis [56] of the $\operatorname{PrPc}^{\mathrm{c}}$ sequence followed by substitution of the degenerate amplified material for the wild type sequence in order to generate a library of random $\mathrm{PrP}^{c}$ mutations fused to GFP (see 1). Nucleotide sequencing of several library members picked at random showed a variety of sequence changes causing premature stop codons as well as single or multiple amino acid changes within the PrPc coding region (not shown). To select altered folding variants the library was plated at high density, replicated to agar plates containing IPTG and colonies were screened for fluorescence following irradiation with ultraviolet light. The overall number of fluorescent colonies was low and after eradication of false positives three mutants (M17, M22 and M25), which showed particularly strong fluorescence, (Fig. 3) were isolated and characterised further. As a recovery in fluorescence could indicate a change in folding and solubility bacterial cultures of the parental construct and each fluorescent variant were induced, harvested and lysed and the level of $\mathrm{PrPc}_{-}$GFP fusion protein present in the soluble and insoluble fractions was assessed by western blot using the $\mathrm{PrPc}^{\mathrm{c}}$ monoclonal antibody 6H4 (epitope 144-152). As noted the parental sequence was wholly insoluble but significant amounts of the fusion protein from variants $\mathrm{M} 22$ and M25 and approximately $50 \%$ of the protein from mutant M17 were found in the supernatant fraction (Fig. 4). One variant (M22) showed substantial proteolysis leading to loss of full length antibody reactive material in the supernatant fraction, a characteristic of soluble $\mathrm{PrP}^{\mathrm{c}}$ expression in E.coli [57]. DNA sequencing of each variant revealed that M22 and M25 each had two amino acid changes, E152V+N48S and Y149H+G228E respectively while variant M17 showed only a single amino acid change at H84Q (Figure 5). Thus, changes of as little as one or two amino acids throughout the $\operatorname{PrPc}^{\mathrm{c}}$ polypeptide chain can cause significant alteration in protein folding. None of the mutations selected by this procedure occurred in the prion hydrophobic sequence (amino acids 111-133) rather, as suggested, change of charge was the predominant feature observed [58]. 


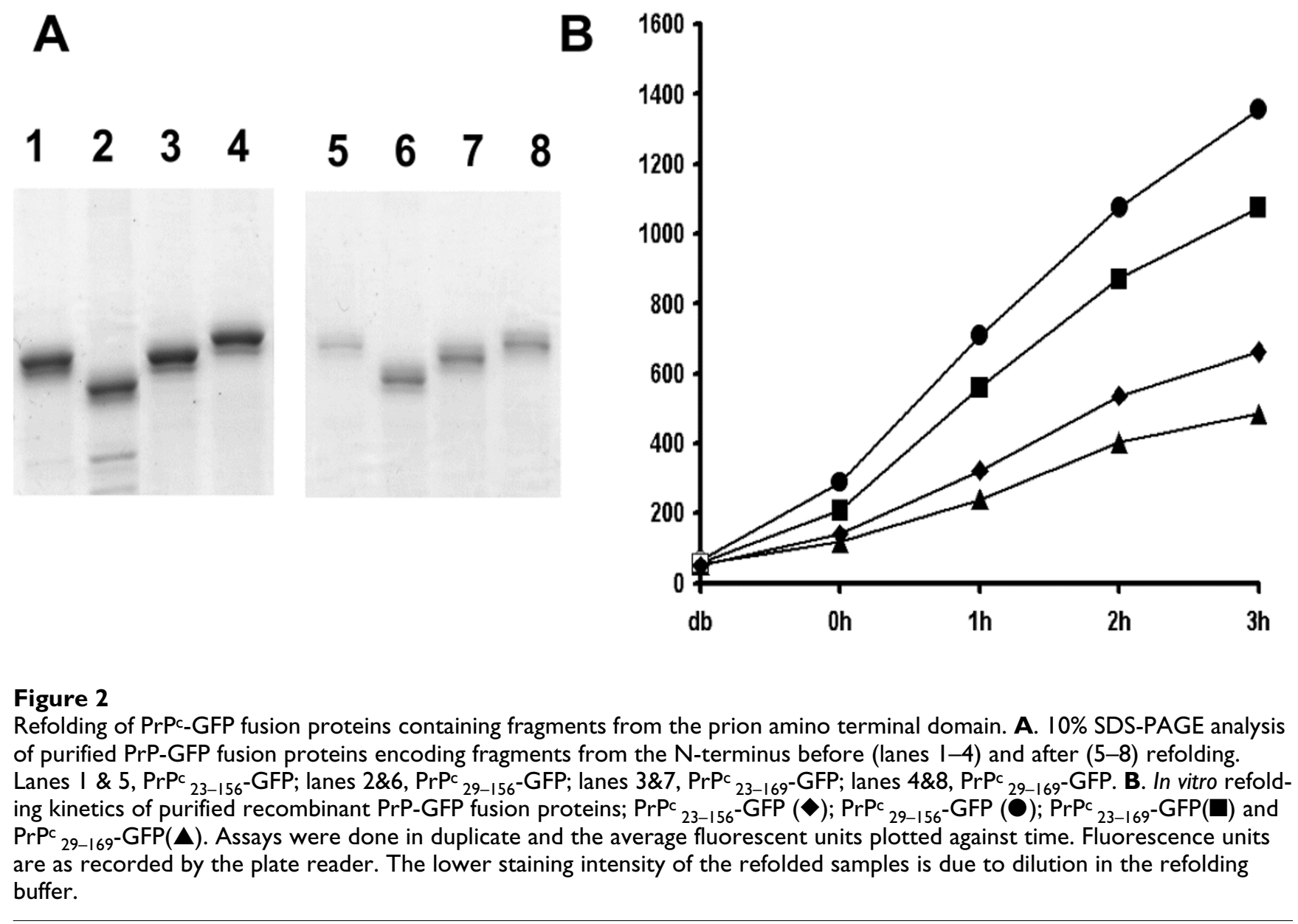

\section{Discussion}

The use of protein fusions as reporters of protein folding and solubility has emerged rapidly and includes use of chloramphenicol acetyltransferase (CAT) [59], $\beta$-galactosidase $[60,61]$ and secretion by defined bacterial translocation systems [62]. The most well defined system however has been fusion to the $N$ terminus of GFP [40,42] although fusions within the loops of the folded structure have also been reported [63]. The requirement for increased folding and solubility has been largely driven by the production of proteins for structural studies [64] but studies with known misfolding proteins such as Alzheimer's amyloid beta peptide have shown that they can be equally applied to the study of folding per se [60,62]. Here we showed that fusion of GFP to the C-terminus of the mouse prion protein or fragments thereof can provide a measure of the role of prion sequence in folding in vitro and that direct selection of fluorescence in vivo results in PrPc-GFP fusion proteins with altered proprieties of solubility. Refolding of PrPc-GFP fusions was found to be robust and not to result in degradation but marked variation in efficiency was noted when the refolding of individ- ual fragments of $\mathrm{PrPc}^{\mathrm{c}}$ was investigated. In particular, the presence or not of residues 23-28 (KKRPKP), highly conserved in prion sequences [65], substantially affected refolding in vitro and mirrored their affect on PrPc-GFP fusion protein expression in vivo [43]. The diverse biological properties of this region, including binding of prion protein to charged molecules such as Heparin and GAGs [66-69], suramin [70] and cellular routing [53,54] would be consistent with a role on the overall structure of the prion protein. Indeed, restricting movement by N-terminal tethering of $\mathrm{PrPc}^{\mathrm{c}}$ to the cell surface abrogates the only known function of the protein, cellular resistance to oxidative stress [71]. Previous antibody binding studies have suggested that the prion $\mathrm{N}$-terminus may contact the carboxyl domain [72] and we have previously suggested this interaction may occur between the basic amino terminus and the acidic patch in helix- $1\left({ }_{143} \mathrm{DWED}_{146}\right)$ [43]. Matsunaga et al., using an N-terminally truncated $\mathrm{PrPc}^{\mathrm{c}}$ molecule, previously proposed a model in which the free $\mathrm{N}$-terminal amine of $\mathrm{PrPc}^{\mathrm{C}}$ residue 90 (the truncation point) interacted with the acidic charge cluster in helix-1 following the observation that cryptic epitopes for monoclonal anti- 


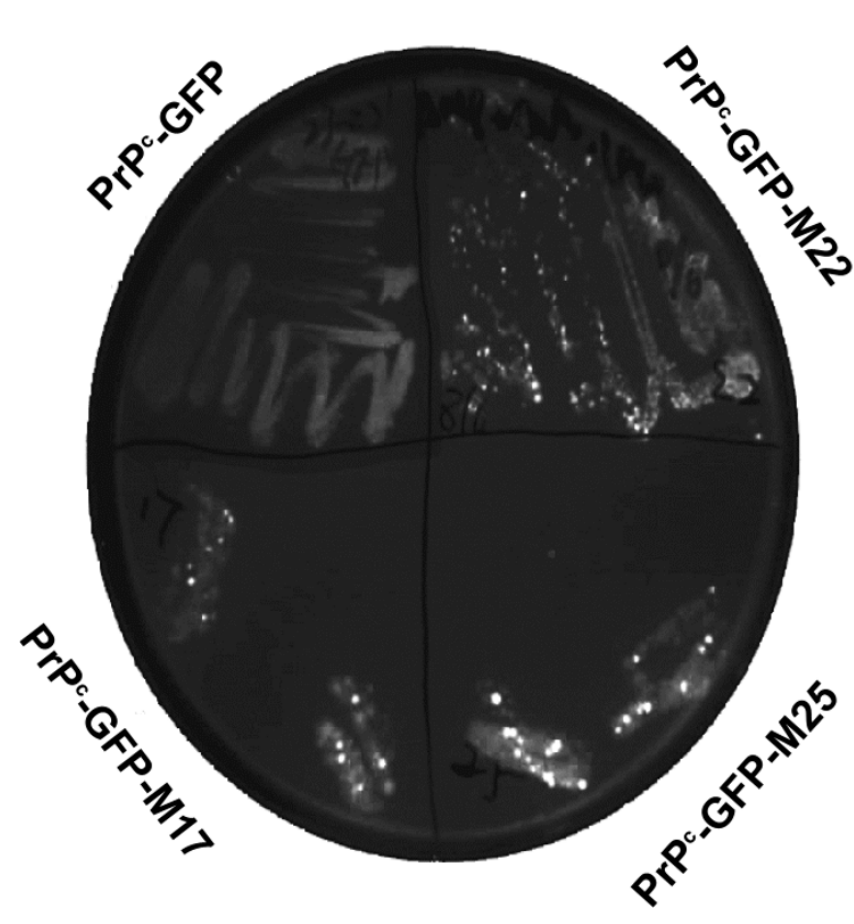

Figure 3

Direct selection of $\mathrm{Pc}_{23-231}$-GFP mutants with increased fluorescence. Fluorescence of the three prion mutants $(17,22$ and 25 ) isolated by the procedures described. Each was grown overnight on agar plates and a heavy inoculum transferred to a sectored agar plate supplemented with IPTG to induce expression of the fusion protein. After three hours at 37 degrees the plate was photographed under UV light.

body $3 \mathrm{~F} 4$ within the $\mathrm{N}$-terminus are revealed by titration of acidic residues around Glu 152 [55]. The GFP fluorescence recovery assay described here supports this model but suggests it is residues 23-28 that have a direct role in folding, consistent with binding to the carboxyl domain described elsewhere [43]. While various properties have been ascribed to this short section of charged residues $[43,53,54,67,68,70,73]$ use of refolding in vitro indicates for the first time that these observations could be the result of a role in the overall folding of the molecule.

A corollary of prion sequence identity affecting refolding in vitro is that direct selection of fluorescence from the non-fluorescent PrPc $23-231$-GFP should result in altered solubility. To assess this we carried out forced evolution of the $\operatorname{PrPc}^{\mathrm{c}}$ sequence and used GFP to screen for a fluorescent outcome. Model experiments have suggested that as little a change as one amino acid can have a profound effect on the physiochemical properties of complete proteins such as $\alpha$-synuclein but the effect of mutations associated with PrPc has been only tested on isolated peptides [74] making the same conclusion for the complete prion protein uncertain. Three mutants isolated by virtue of their fluo-

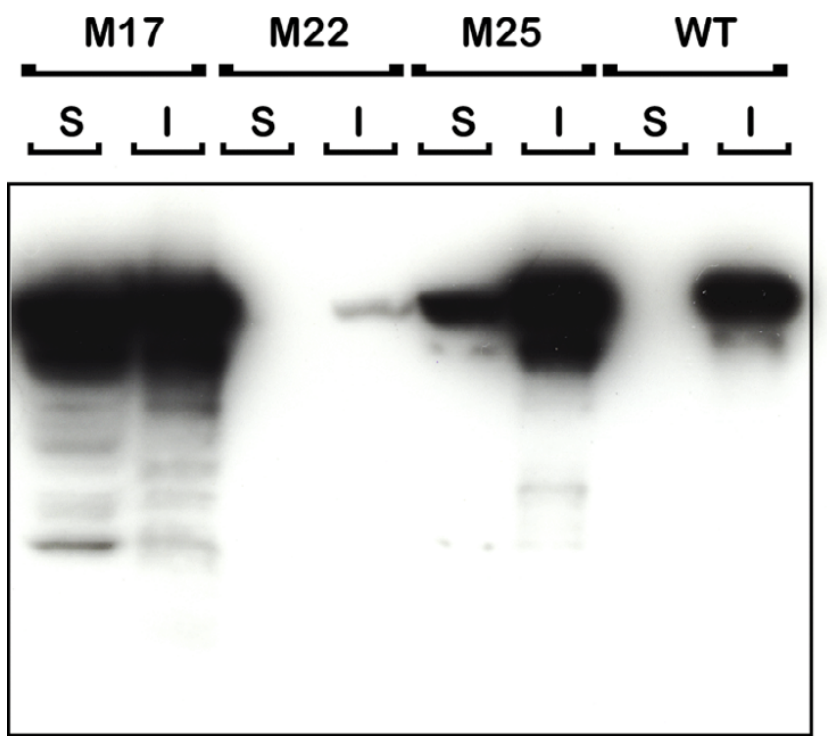

Figure 4

Mutants $M I 7,22$ and 25 , selected by recovery of fluorescence, were grown and PrPc_GFP fusion protein present in the soluble (S) and insoluble (I) fractions of each induced culture after detergent lysis were resolved by 10\% SDS-PAGE and probed with the prion monoclonal antibody $6 \mathrm{H} 4$. Reaction with mutant M22 has been largely lost due to degradation in the soluble phase and only residual insoluble material is detected.

rescence had either one or two residue changes when compared to the parental sequence. Changes at residue 84 (mutant 17) and 47 (part of mutant M22) were outside of the known prion structure [17] but in the case of residue M17 changed the character of the residue from charged to neutral. Of particular interest however is that one each of the double mutations, E151V (mutant M22) and Y148H (mutant M25) lie in the first alpha helix suggested to interact with the $\mathrm{N}$ terminus $[43,55]$ and mapped to be the site of interaction of a major $\mathrm{PrPc}$ ligand, the laminin receptor [75] (Figure 6). In addition the majority of changes identified were charged residues (Figure 5). Change of net charge, particularly among the familial forms of amyloid disease proteins has been suggested to have a major effect on protein solubility $[58,74]$. None of the mutations associated with improved solubility coincide directly with known prion polymorphisms although interestingly residue 84 (mutant M17) is the point of several octarepeat insertions associated with GerstmannSträussler-Scheinker Syndrome [76,77]. However, although our data add direct experimental support to the notion that prion protein folding is very susceptible to minor changes of sequence, it does not directly address the role of prion protein solubility in the pathogenicity of prion disease. 


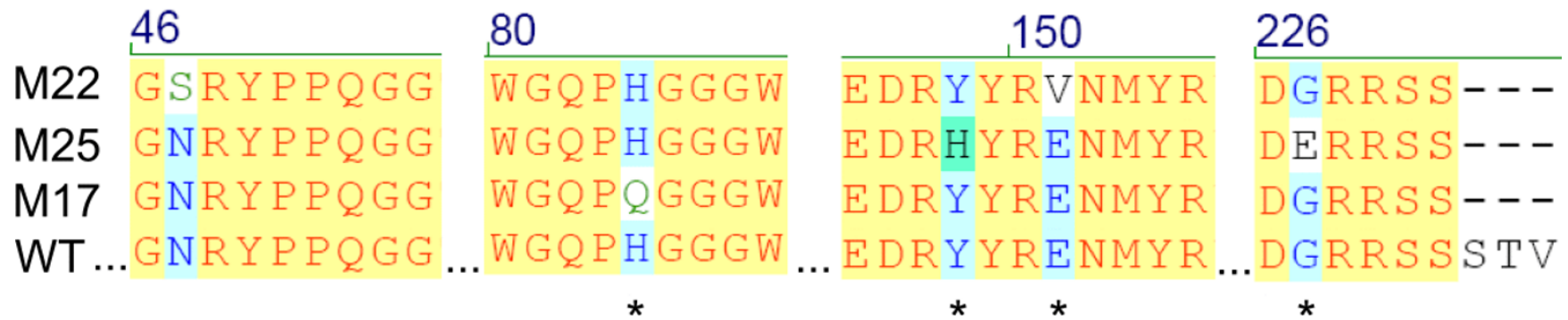

\section{Figure 5}

Sequence alignment of mutants MI7, 22 and 25 compared to the mouse wild type sequence. Only those areas showing changes are shown. Amino acid changes that cause a change of net charge are indicated by the asterisk below the aligned sequence.

\section{Conclusion}

Prion protein misfolding is thought to underlie its involvement with the TSE diseases and its study, directly or indirectly, may help determine the molecular mechanisms involved. Use of GFP as a folding reporter has been well described but its use as a probe of prion innate folding rather than cellular targeting has not been previously reported. The GFP fluorescence assay we have described may be useful for assessing a number of prion mutations

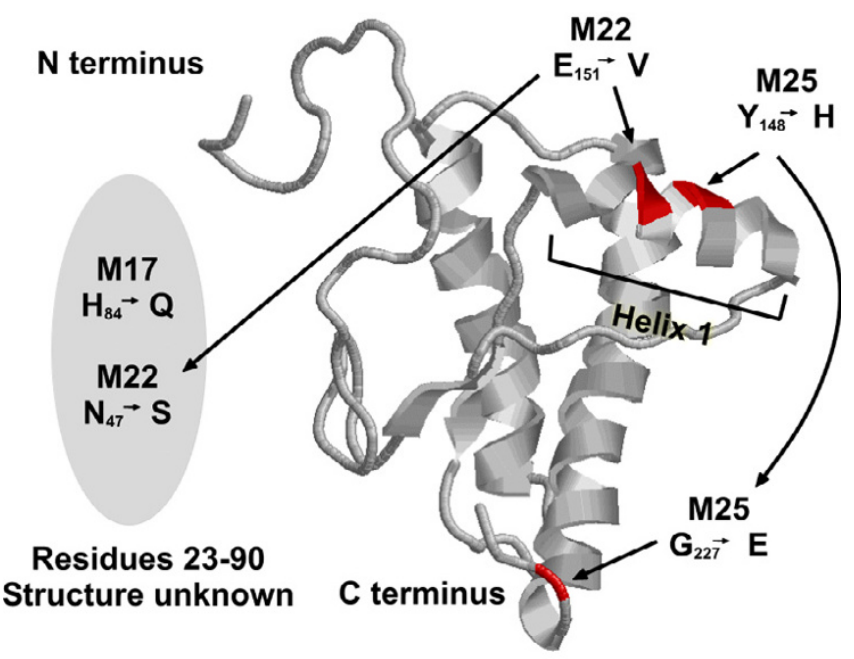

Figure 6

Location of the mutations selected by fluorescence recovery in the three dimensional structure of the prion protein. The unstructured amino terminus up to residue 90 is represented by the grey oval. The amino and carboxyl termini of the solved structure and the location of helix I are indicated. and the interaction of $\operatorname{PrPc}^{\mathrm{c}}$ with its various reported ligands [78].

\section{Methods}

\section{E.coli strains}

E.coli Top 10 (Invitrogen) was used throughout for cloning. Plasmids were transformed into E.coli BL21 DE3 (pLysS) (Novagen) for T7 driven protein production.

\section{Plasmid construction}

Mouse Prnpa allele (accession A23544) and enhanced green fluorescence protein (accession AAC53663) were used throughout. cDNA fragments encoding amino acids 23-231 and the N-terminal residues 23-156, 29-156, 76-156, 23-169 and 29-169 were amplified by the polymerase chain reaction (PCR) to be flanked by restriction sites for Bam $\mathrm{H} 1$ and first cloned into baculovirus

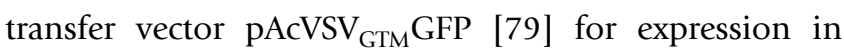
insect cells [43]. Each construct was then used as a template to amplify the sequence encoding the fusion of $\mathrm{PrPc}^{\mathrm{c}}$ and eGFP flanking the sequence with restriction sites Nde1 and Xho1 at the $5^{\prime}$ at the 3 ' ends respectively. Fragments were digested with the same enzymes and cloned into pET23a (Novagen) through the same sites to produce $\mathrm{PrP}^{\mathrm{c}}$-GFP gene fusions under the control of the T7 promoter.

\section{Expression libraries}

A degenerate library of prion sequences was created by error prone PCR [56] and cloned en masse into pET23a upstream of, and in frame with, a sequence encoding eGFP. Several library members were picked at random for nucleotide sequencing to ensure errors had been introduced. The library was maintained in E.coli BL21 pLysS in an un-induced state and induced for fluorescence screening by replica plating to agar containing $2 \mathrm{mM}$ IPTG. Col- 
onies were screened visually after a further 5 hours incubation and positives re-streaked to ensure positivity bred true. Once confirmed, uninduced colonies were restreaked from the master plate and DNA isolated for sequencing.

\section{Purification of inclusion bodies (IBs)}

IBs were prepared by a modified differential solubility regime [80]. Following inoculation of a single colony into Luria broth cultures were induced with IPTG $(0.2 \mathrm{mM})$ at an OD600 of 0.5. Cultures were grown for a further 2 hours and bacteria harvested by centrifugation at 4500 $\mathrm{rpm}$ for 20 minutes at $4{ }^{\circ} \mathrm{C}$. The pellet was resuspended in $10 \mathrm{ml}$ PBS and the IBs released by sonication on ice for 10 minutes, $1 \%$ triton X-100 (v/v) was added to complete solublization and the IBs collected by centrifugation at $4500 \mathrm{rpm}$ for 10 minutes. The pellet was washed repeatedly with $1 \%$ Triton X-100 until the purity of the IBs was at least $90 \%$ as judged by SDS-PAGE.

\section{Protein refolding}

IBs were denatured and reduced at $95^{\circ} \mathrm{C}$ for 5 minute in $4 \mathrm{M}$ Urea and then clarified by ultracentrifugation. Refolding was initiated by a single $7 \times$ dilution step into a buffer containing $50 \mathrm{mM}$ Tris. $\mathrm{HCl}$ pH8.5, $1 \mathrm{mM} \mathrm{KCl}, 2 \mathrm{mM}$ $\mathrm{MgCl}_{2}$. Recovery of fluorescence over time was monitored by periodic fluorescence measurement at $510 \mathrm{~nm}$ in a Genios microplate reader (Tecan). Assays were done in duplicate and the average fluorescent units plotted against time. To assess the role of metal ions in refolding buffers were depleted for ions my mixing with chelex-100 (BioRad) as described [25] and filtering prior to constitution of the assay. Ranging studies showed that the addition of copper above 10 micromolar was found to be generally inhibitory (i.e. inhibited the refolding of GFP only).

\section{Purification of RNA}

Total RNA for inclusion in the refolding assay was prepared from SNB cells as described for RNA that stimulates PrPc-PrPSc conversion [51]. Briefly, cells were washed with PBS and resuspended in $1 \mathrm{ml}$ of Trizol (Invitrogen). The lysate was extracted with chloroform and the RNA recovered by precipitation with isopropanol. The pellet was washed with 75\% ethanol, air dried, resuspended in RNAase free water and quantitated by $\mathrm{A}_{260}$.

\section{Protease $K$ digestion}

RNA stimulated partial protection of $\operatorname{PrPc}^{\mathrm{c}}$ was assessed by digestion of the reaction products after refolding with protease $\mathrm{K}$ as described [52].

\section{Western blotting}

Protein samples to be analyzed were separated on pre-cast $10 \%$ Tris-HCl SDS-polyacrylamide gels (Bio-Rad) and transferred onto Immobilon-P transfer membrane (Milli- pore). Western blotting was performed as described (Burnette, 1981) except that sensitivity was increased through the use of a biotin conjugated secondary antibody followed by extravidin-peroxidase (Sigma). The membrane was finally developed with BM Chemiluminescence (Roche). The primary antibodies used were prion monoclonal antibodies 6H4 (Prionics) and anti-GFP (Clontech).

\section{Competing interests}

The author(s) declare that they have no competing interests.

\section{Authors' contributions}

SV and JYR developed the in vitro refolding and random library mutagenesis protocols respectively. YY, KD and CSD contributed various constructs and assays and IMJ conceived, planned and advised throughout the study. All authors contributed to the writing of the manuscript.

\section{Additional material}

\section{Additional File 1}

Additional figure 1. Shows the role of copper ions and RNA on in vitro refolding of $\operatorname{PrP}_{23-231}$-GFP using the standard assay described in the manuscript.

Click here for file

[http://www.biomedcentral.com/content/supplementary/1743422X-3-59-S1.tiff]

\section{Additional File 2}

Additional figure 2. Cartoon representation of the PrPc expression constructs used to investigate the role of the $N$ terminal sequence on refolding in vitro.

Click here for file

[http://www.biomedcentral.com/content/supplementary/1743422X-3-59-S2.tiff]

\section{Additional File 3}

Additional figure 3. Cartoon and flow diagram of the process for random selection of soluble variants of $\mathrm{PrP}^{c_{-}} \mathrm{GFP}$ by virtue of mutations that allow fluorescence in vivo.

Click here for file

[http://www.biomedcentral.com/content/supplementary/1743422X-3-59-S3.tiff]

\section{Acknowledgements}

We thank Barbara Konig for technical assistance and the UK Medical Research Council and Department for Environment, Food and Rural Affairs (DEFRA) for grant support.

\section{References}

I. Basler K, Oesch B, Scott M, Westaway D, Walchli M, Groth DF, McKinley MP, Prusiner SB, Weissmann C: Scrapie and cellular PrP isoforms are encoded by the same chromosomal gene. Cell 1986, 46:417-428. 
2. Safar J, Prusiner SB: Molecular studies of prion diseases. Prog Brain Res 1998, I I7:421-434.

3. Stockel J, Safar J, Wallace AC, Cohen FE, Prusiner SB: Prion protein selectively binds copper(II) ions. Biochemistry 1998 37:7I85-7193.

4. Wong BS, Venien-Bryan C, Williamson RA, Burton DR, Gambetti P, Sy MS, Brown DR, Jones IM: Copper refolding of prion protein. Biochem Biophys Res Commun 2000, 276:1217-1224.

5. Quaglio E, Chiesa R, Harris DA: Copper converts the cellular prion protein into a protease-resistant species that is distinct from the scrapie isoform. J Biol Chem 200I, 276: I I432-I I 438

6. Jackson GS, Murray I, Hosszu LL, Gibbs N, Waltho JP, Clarke AR, Collinge J: Location and properties of metal-binding sites on the human prion protein. Proc Natl Acad Sci U S A 2001 98:853|-8535

7. Horwich AL, Weissman JS: Deadly conformations--protein misfolding in prion disease. Cell 1997, 89:499-510.

8. Liemann S, Glockshuber R: Transmissible spongiform encephalopathies. Biochem Biophys Res Commun 1998, 250:187-193.

9. Prusiner SB, Scott MR: Genetics of prions. Annu Rev Genet 1997 3I:139-175

10. Brown DR, Schulz-Schaeffer WJ, Schmidt B, Kretzschmar HA: Prion protein-deficient cells show altered response to oxidative stress due to decreased SOD-I activity. Exp Neurol 1997, I46: 104-II2.

II. Guentchev M, Voigtlander T, Haberler C, Groschup MH, Budka H Evidence for oxidative stress in experimental prion disease. Neurobiol Dis 2000, 7:270-273.

12. Milhavet O, McMahon HE, Rachidi W, Nishida N, Katamine S, Mange A, Arlotto M, Casanova D, Riondel J, Favier A, Lehmann S: Prion infection impairs the cellular response to oxidative stress. Proc Natl Acad Sci U S A 2000, 97: I 3937-I 3942.

13. Wong BS, Pan T, Liu T, Li R, Petersen RB, Jones IM, Gambetti P, Brown DR, Sy MS: Prion disease: A loss of antioxidant function? Biochem Biophys Res Commun 2000, 275:249-252.

14. Kim Jl, Choi SI, Kim NH, Jin JK, Choi EK, Carp RI, Kim YS: Oxidative stress and neurodegeneration in prion diseases. Ann N Y Acad Sci 200I, 928:182-I86.

15. Turnbull S, Tabner BJ, Brown DR, Allsop D: Copper-dependent generation of hydrogen peroxide from the toxic prion protein fragment PrP 106-126. Neurosci Lett 2003, 336:159-162.

16. Rachidi W, Vilette D, Guiraud P, Arlotto M, Riondel J, Laude H, Lehmann S, Favier A: Expression of prion protein increases cellular copper binding and antioxidant enzyme activities but not copper delivery. I Biol Chem 2003, 278:9064-9072.

17. Riek R, Hornemann S, Wider G, Billeter M, Glockshuber R, Wuthrich $\mathrm{K}$ : NMR structure of the mouse prion protein domain $\operatorname{PrP}(12$ I-32I). Nature 1996, 382:180-I82.

18. Wildegger G, Liemann S, Glockshuber R: Extremely rapid folding of the C-terminal domain of the prion protein without kinetic intermediates. Nat Struct Biol 1999, 6:550-553.

19. Glockshuber R: Folding dynamics and energetics of recombinant prion proteins. Adv Protein Chem 200I, 57:83-105.

20. Donne DG, Viles JH, Groth D, Mehlhorn I, James TL, Cohen FE, Prusiner SB, Wright PE, Dyson HJ: Structure of the recombinant full-length hamster prion protein $\operatorname{PrP}(29-23 I)$ : the $\mathbf{N}$ terminus is highly flexible [see comments]. Proc Natl Acad Sci U S A 1997, 94:13452-13457.

21. Zahn R, Liu A, Luhrs T, Riek R, von Schroetter C, Lopez Garcia F, Billeter M, Calzolai L, Wider G, Wuthrich K: NMR solution structure of the human prion protein. Proc Natl Acad Sci U S A 2000, 97: $145-150$.

22. Brown DR, Qin K, Herms JW, Madlung A, Manson J, Strome R, Fraser PE, Kruck T, von Bohlen A, Schulz-Schaeffer W, Giese A, Westaway $\mathrm{D}, \mathrm{Kretzschmar} \mathrm{H}$ : The cellular prion protein binds copper in vivo. Nature 1997, 390:684-687.

23. Perera WS, Hooper NM: Ablation of the metal ion-induced endocytosis of the prion protein by disease-associated mutation of the octarepeat region. Curr Biol 200I, I I:5 19-523.

24. Kramer ML, Kratzin HD, Schmidt B, Romer A, Windl O, Liemann S, Hornemann S, Kretzschmar H: Prion protein binds copper within the physiological concentration range. J Biol Chem 200I, 276: $167 \mid 1-16719$.

25. Jobling MF, Huang X, Stewart LR, Barnham KJ, Curtain C, Volitakis I, Perugini M, White AR, Cherny RA, Masters CL, Barrow C], Collins S], Bush Al, Cappai R: Copper and zinc binding modulates the aggregation and neurotoxic properties of the prion peptide PrPI 06-I 26. Biochemistry 200I, 40:8073-8084.

26. Qin K, Yang Y, Mastrangelo P, Westaway D: Mapping Cu(II) binding sites in prion proteins by diethyl pyrocarbonate modification and matrix-assisted laser desorption ionization-time of flight (MALDI-TOF) mass spectrometric footprinting. J Biol Chem 2002, 277: 1981-1990.

27. Flechsig E, Shmerling D, Hegyi I, Raeber AJ, Fischer M, Cozzio A, von Mering C, Aguzzi A, Weissmann C: Prion protein devoid of the octapeptide repeat region restores susceptibility to scrapie in PrP knockout mice. Neuron 2000, 27:399-408.

28. Leclerc E, Peretz D, Ball H, Sakurai H, Legname G, Serban A, Prusiner $S B$, Burton DR, Williamson RA: Immobilized prion protein undergoes spontaneous rearrangement to a conformation having features in common with the infectious form. Embo J 200I, 20: I547-I554.

29. Peretz D, Williamson RA, Legname G, Matsunaga $Y$, Vergara J, Burton DR, DeArmond SJ, Prusiner SB, Scott MR: A change in the conformation of prions accompanies the emergence of a new prion strain. Neuron 2002, 34:921-932.

30. Dobson CM: Getting out of shape. Nature 2002, 4I 8:729-730.

3I. Bucciantini M, Giannoni E, Chiti F, Baroni F, Formigli L, Zurdo J, Taddei N, Ramponi G, Dobson CM, Stefani M: Inherent toxicity of aggregates implies a common mechanism for protein misfolding diseases. Nature 2002, 416:507-5II.

32. Dobson CM: Protein folding and misfolding. Nature 2003, 426:884-890

33. Rachidi W, Mange A, Senator A, Guiraud P, Riondel J, Benboubetra M, Favier A, Lehmann S: Prion Infection Impairs Copper Binding of Cultured Cells. J Biol Chem 2003, 278: I4595-I4598.

34. Mani K, Cheng F, Havsmark B, Jonsson M, Belting M, Fransson LA Prion or amyloid-b-derived $\mathrm{Cu}$ (II)- or free $\mathrm{Zn}$ (II)-ions support S-nitroso-dependent autocleavage of glypican-I heparan sulfate. J Biol Chem 2003:M300394200.

35. Peretz D, Williamson RA, Kaneko K, Vergara J, Leclerc E, SchmittUlms G, Mehlhorn IR, Legname G, Wormald MR, Rudd PM, Dwek RA, Burton DR, Prusiner SB: Antibodies inhibit prion propagation and clear cell cultures of prion infectivity. Nature 200I, 4I 2:739-743.

36. Enari M, Flechsig E, Weissmann C: Scrapie prion protein accumulation by scrapie-infected neuroblastoma cells abrogated by exposure to a prion protein antibody. Proc Natl Acad Sci U S A 200I, 98:9295-9299.

37. White AR, Enever P, Tayebi M, Mushens R, Linehan J, Brandner S, Anstee D, Collinge J, Hawke S: Monoclonal antibodies inhibit prion replication and delay the development of prion disease. Nature 2003, 422:80-83.

38. Meier P, Genoud N, Prinz M, Maissen M, Rulicke T, Zurbriggen A Raeber AJ, Aguzzi A: Soluble Dimeric Prion Protein Binds PrP(Sc) In Vivo and Antagonizes Prion Disease. Cell 2003, I I 3:49-60.

39. Solforosi L, Criado JR, McGavern DB, Wirz S, Sanchez-Alavez M, Sugama S, DeGiorgio LA, Volpe BT, Wiseman E, Abalos G, Masliah E, Gilden D, Oldstone MB, Conti B, Williamson RA: Cross-linking cellular prion protein triggers neuronal apoptosis in vivo. Science 2004, 303:|5|4-15|6.

40. Waldo GS, Standish BM, Berendzen J, Terwilliger TC: Rapid protein-folding assay using green fluorescent protein. Nat Biotechnol 1999, I7:69|-695.

4I. Pedelacq JD, Piltch E, Liong EC, Berendzen J, Kim CY, Rho BS, Park MS, Terwilliger TC, Waldo GS: Engineering soluble proteins for structural genomics. Nat Biotechnol 2002, 20:927-932.

42. Waldo GS: Improving protein folding efficiency by directed evolution using the GFP folding reporter. Methods Mol Biol 2003, 230:343-359.

43. Yao $\mathrm{Y}$, Ren J, Jones IM: Amino terminal interaction in the prion protein identified using fusion to green fluorescent protein. Neurochem 2003, 87: 1057-1065.

44. Cubitt AB, Woollenweber LA, Heim R: Understanding structurefunction relationships in the Aequorea victoria green fluorescent protein. Methods Cell Biol I999, 58:19-30.

45. Heim R, Prasher DC, Tsien RY: Wavelength mutations and posttranslational autoxidation of green fluorescent protein. Proc Natl Acad Sci U S A 1 994, 9 I: I 250 I- 12504.

46. Reid BG, Flynn GC: Chromophore formation in green fluorescent protein. Biochemistry 1997, 36:6786-679I. 
47. Fukuda $\mathrm{H}$, Arai $\mathrm{M}$, Kuwajima K: Folding of green fluorescent protein and the cycle3 mutant. Biochemistry 2000, 39: I 2025-I 2032.

48. Viles JH, Cohen FE, Prusiner SB, Goodin DB, Wright PE, Dyson HJ: Copper binding to the prion protein: Structural implications of four identical cooperative binding sites. Proc Natl Acad Sci U S A 1999, 96:2042-2047.

49. Brown DR: Prion protein expression modulates neuronal copper content. J Neurochem 2003, 87:377-385.

50. Gabus C, Derrington E, Leblanc P, Chnaiderman J, Dormont D, Swietnicki W, Morillas M, Surewicz WK, Marc D, Nandi P, Darlix JL: The prion protein has RNA binding and chaperoning properties characteristic of nucleocapsid protein NCP7 of HIV-I. J Biol Chem 200I, 276:1930I-19309.

5I. Deleault NR, Lucassen RW, Supattapone S: RNA molecules stimulate prion protein conversion. Nature 2003, 425:717-720.

52. Adler V, Zeiler B, Kryukov V, Kascsak R, Rubenstein R, Grossman A: Small, highly structured RNAs participate in the conversion of human recombinant $\operatorname{PrP}($ Sen) to $\operatorname{PrP}($ Res) in vitro. J Mol Biol 2003, 332:47-57.

53. Nunziante M, Gilch S, Schatzl HM: Essential role of the prion protein $\mathbf{N}$ terminus in subcellular trafficking and half-life of cellular prion protein. J Biol Chem 2003, 278:3726-3734.

54. Sunyach C, Jen A, Deng J, Fitzgerald KT, Frobert $Y$, Grassi J, McCaffrey MW, Morris R: The mechanism of internalization of glycosylphosphatidylinositol-anchored prion protein. Embo 2003, 22:359|-360।.

55. Matsunaga Y, Peretz D, Williamson A, Burton D, Mehlhorn I, Groth $\mathrm{D}$, Cohen FE, Prusiner SB, Baldwin MA: Cryptic epitopes in N-terminally truncated prion protein are exposed in the fulllength molecule: dependence of conformation on $\mathrm{pH}$. Proteins 200I, 44: II0-II8.

56. Crameri A, Whitehorn EA, Tate E, Stemmer WP: Improved green fluorescent protein by molecular evolution using DNA shuffling. Nat Biotechnol 1996, 14:315-319.

57. Hornemann S, Korth C, Oesch B, Riek R, Wider G, Wuthrich K, Glockshuber R: Recombinant full-length murine prion protein, $\mathrm{mPrP}(23-23 \mathrm{I})$ : purification and spectroscopic characterization. FEBS Lett 1997, 413:277-28I.

58. Chiti F, Calamai M, Taddei N, Stefani M, Ramponi G, Dobson CM: Studies of the aggregation of mutant proteins in vitro provide insights into the genetics of amyloid diseases. Proc Nat Acad Sci U S A 2002, 99 Suppl 4:16419-16426.

59. Maxwell KL, Mittermaier AK, Forman-Kay JD, Davidson AR: A simple in vivo assay for increased protein solubility. Protein $\mathrm{SC}$ 1999, 8:1908-19|1.

60. Wigley WC, Stidham RD, Smith NM, Hunt JF, Thomas PJ: Protein solubility and folding monitored in vivo by structural complementation of a genetic marker protein. Nat Biotechnol 200I, 19:131-136.

61. Stidham RD, Wigley WC, Hunt JF, Thomas PJ: Assessment of protein folding/solubility in live cells. Methods Mol Biol 2003 205: $155-169$.

62. Fisher AC, Kim W, DeLisa MP: Genetic selection for protein solubility enabled by the folding quality control feature of the twin-arginine translocation pathway. Protein Sci 2006, 15:449-458.

63. Cabantous S, Pedelacq JD, Mark BL, Naranjo C, Terwilliger TC Waldo GS: Recent advances in GFP folding reporter and splitGFP solubility reporter technologies. Application to improving the folding and solubility of recalcitrant proteins from Mycobacterium tuberculosis. J Struct Funct Genomics 2005, 6:113-119.

64. Waldo GS: Genetic screens and directed evolution for protein solubility. Curr Opin Chem Biol 2003, 7:33-38.

65. Wopfner F, Weidenhofer G, Schneider R, von Brunn A, Gilch S, Schwarz TF, Werner T, Schatzl HM: Analysis of $\mathbf{2 7}$ mammalian and 9 avian PrPs reveals high conservation of flexible regions of the prion protein. J Mol Biol 1999, 289: II63-1178.

66. Snow AD, Wight TN, Nochlin D, Koike Y, Kimata K, DeArmond SJ, Prusiner SB: Immunolocalization of heparan sulfate proteoglycans to the prion protein amyloid plaques of GerstmannStraussler syndrome, Creutzfeldt-Jakob disease and scrapie. Lab Invest 1990, 63:601-611.

67. Warner RG, Hundt C, Weiss S, Turnbull JE: Identification of the heparan sulfate binding sites in the cellular prion protein. Biol Chem 2002, 277: 1842 I-18430.
68. Pan T, Wong BS, Liu T, Li R, Petersen RB, Sy MS: Cell surface prion protein interacts with glycosaminoglycans. Biochem J 2002, 368:81-90.

69. Gonzalez-Iglesias R, Pajares MA, Ocal C, Espinosa JC, Oesch B, Gasset $M$ : Prion protein interaction with glycosaminoglycan occurs with the formation of oligomeric complexes stabilized by $\mathrm{Cu}$ (II) bridges. I Mol Biol 2002, 3 I9:527-540.

70. Gilch S, Winklhofer KF, Groschup MH, Nunziante M, Lucassen R, Spielhaupter C, Muranyi W, Riesner D, Tatzelt J, Schatzl HM: Intracellular re-routing of prion protein prevents propagation of $\operatorname{PrP}(\mathrm{Sc})$ and delays onset of prion disease. Embo J 200I, 20:3957-3966.

7I. Zeng F, Watt NT, Walmsley AR, Hooper NM: Tethering the $\mathbf{N}$ terminus of the prion protein compromises the cellular response to oxidative stress. INeurochem 2003, 84:480-490.

72. Li R, Liu T, Wong BS, Pan T, Morillas M, Swietnicki W, O'Rourke K, Gambetti P, Surewicz WK, Sy MS: Identification of an epitope in the $C$ terminus of normal prion protein whose expression is modulated by binding events in the $\mathbf{N}$ terminus. I Mol Biol 2000, 30 I:567-573.

73. Brimacombe DB, Bennett AD, Wusteman FS, Gill AC, Dann JC, Bostock $C$ J: Characterization and polyanion-binding properties of purified recombinant prion protein. Biochem J I999, $342 \mathrm{Pt}$ 3:605-6I3.

74. Chiti F, Stefani M, Taddei N, Ramponi G, Dobson CM: Rationalization of the effects of mutations on peptide and protein aggregation rates. Nature 2003, 424:805-808.

75. Hundt C, Peyrin JM, Haik S, Gauczynski S, Leucht C, Rieger R, Riley $M L$, Deslys JP, Dormont D, Lasmezas $\mathrm{Cl}$, Weiss S: Identification of interaction domains of the prion protein with its $37-\mathrm{kDa} / 67$. kDa laminin receptor. Embo J 200I, 20:5876-5886.

76. Goldfarb LG, Brown P, Vrbovska A, Baron H, McCombie WR, Cathala F, Gibbs CJJ, Gajdusek DC: An insert mutation in the chromosome 20 amyloid precursor gene in a GerstmannStraussler-Scheinker family. J Neurol Sci 1992, I I I: 189-194.

77. Laplanche JL, Hachimi KH, Durieux I, Thuillet P, Defebvre L, Delasnerie-Laupretre N, Peoc'h K, Foncin JF, Destee A: Prominent psychiatric features and early onset in an inherited prion disease with a new insertional mutation in the prion protein gene. Brain 1999, I 22 ( Pt | 2):2375-2386.

78. Gauczynski S, Hundt C, Leucht C, Weiss S: Interaction of prion proteins with cell surface receptors, molecular chaperones, and other molecules. Adv Protein Chem 200I, 57:229-272.

79. Chapple SD, Jones IM: Non-polar distribution of green fluorescent protein on the surface of Autographa californica nucleopolyhedrovirus using a heterologous membrane anchor. J Biotechnol 2002, 95:269-275.

80. Chan DC, Fass D, Berger JM, Kim PS: Core structure of gp4। from the HIV envelope glycoprotein. Cell 1997, 89:263-273.
Publish with Bio Med Central and every scientist can read your work free of charge

"BioMed Central will be the most significant development for disseminating the results of biomedical research in our lifetime. "

Sir Paul Nurse, Cancer Research UK

Your research papers will be:

- available free of charge to the entire biomedical community

- peer reviewed and published immediately upon acceptance

- cited in PubMed and archived on PubMed Central

- yours - you keep the copyright
BioMedcentral 